\title{
Fins are relevant non-lethal surrogates for muscle to measure stable isotopes in amphibians
}

\author{
Nadège Bélouard ${ }^{1,2, *}$, Eric J. Petit ${ }^{2}$, Dominique Huteau ${ }^{2}$, Adrien Oger ${ }^{1}$, and Jean-Marc Paillisson ${ }^{1}$ \\ ${ }^{1}$ UMR 6553 ECOBIO, CNRS, Univ Rennes, 35042 Rennes, France \\ ${ }^{2}$ UMR ESE, Ecologie et Santé des Ecosystèmes, INRA, Agrocampus-Ouest, 35042 Rennes, France
}

\begin{abstract}
Stable isotope analyses (SIA) are now widely used in ecology research to quantify the trophic implications of a large range of ecological processes. Non-destructive sampling methods have been successfully developed for most vertebrates, but the validation of such methods is missing in amphibians. Filling this methodological gap is critical to reduce the significant lack of knowledge on the trophic ecology of this imperilled group. The relevance of tail fin as a surrogate for muscle, a tissue routinely used for SIA, was assessed in four amphibian species, including tadpoles and adult newts, by (1) testing the link between the isotope ratios of carbon and nitrogen in fin and muscle, and addressing the additional practical issues of (2) the effects of a topical anaesthetic on isotope ratios, and (3) the minimum quantities of fin needed for SIA to limit the severity of sampling. The isotope ratios were highly correlated between the two tissues in all four species. Equations were provided to predict muscle estimates from fin values for each species separately and grouped by their taxonomic order (anurans or urodeles), which represent a valuable solution for any other species. Topical anaesthetics had little influence on isotope ratios, and the surface of tail fin needed for SIA was small. We conclude that the tail fin of amphibians can be used as a non-lethal surrogate for muscle in SIA, and this offers promising prospects for research on the trophic ecology of amphibians, and potentially on their conservation.
\end{abstract}

Keywords: Fin biopsy / food web / newt / non-destructive sampling / tadpole

Résumé - La nageoire est un substitut pertinent et non-létal au muscle pour doser les isotopes stables chez les amphibiens. Les analyses d'isotopes stables (AIS) sont maintenant largement utilisées en recherche en écologie pour quantifier les implications trophiques d'une large gamme de processus écologiques. Des méthodes d'échantillonnage non-létales ont été développées chez la plupart des vertébrés, mais une telle validation est absente chez les amphibiens. Il est essentiel de combler cette lacune de façon à réduire le manque de connaissances sur l'écologie trophique de ce groupe menacé. La pertinence de la nageoire caudale comme substitut au muscle, un tissu régulièrement utilisé pour les AIS, a été évaluée chez quatre espèces d'amphibiens, incluant des têtards et des tritons, (1) en testant le lien entre les ratios isotopiques du carbone et de l'azote du muscle et de la nageoire, et en répondant à des questions pratiques comme (2) l'effet d'un anesthésique local sur les ratios isotopiques, et (3) les quantités minimales de nageoire nécessaires aux analyses isotopiques, dans le but de limiter la sévérité de l'échantillonnage. Les ratios isotopiques étaient hautement corrélés entre les deux tissus chez les quatre espèces. Des équations ont été fournies pour prédire les valeurs du muscle à partir de celles de la nageoire en considérant chaque espèce séparément et en les regroupant selon leur ordre taxonomique (anoures ou urodèles) ce qui représente une solution intéressante pour d'autres espèces. L'anesthésique topique a eu une faible influence sur les ratios isotopiques, et la surface de nageoire nécessaire pour les AIS était faible. Nous concluons que la nageoire caudale des amphibiens peut être utilisée en tant que substitut au muscle pour conduire des AIS, ce qui offre des perspectives prometteuses pour la recherche en écologie trophique des amphibiens, et potentiellement pour leur conservation.

Mots-clés : Biopsie de nageoire / échantillonnage non-destructif / réseau trophique / têtard / triton

\footnotetext{
${ }^{*}$ Corresponding author: nadege. belouard@univ-rennes1.fr
} 


\section{Introduction}

Stable isotope analyses (SIA) are now widely used by ecologists to study the trophic-related issues (Fry, 2006; Nielsen et al., 2018). These natural biomarkers provide timeintegrated information on the trophic status of organisms and insights into species interactions notably because the isotopic signature of a consumer's tissues reflects its resources (Fry, 2006; Michener and Lajtha, 2007; Layman et al., 2012). More particularly, the stable isotope ratios of carbon $\left(\delta^{13} \mathrm{C}\right)$ and nitrogen $\left(\delta^{15} \mathrm{~N}\right)$ are the most commonly used tracers in food web studies (Fry, 2006). They can be obtained from whole bodies or internal tissues (e.g. muscle, liver or bones) when their size is sufficient for SIA, although non-destructive tissue collection is preferable for both ethical and epistemological reasons, especially when studying rare or vulnerable species (Hette-Tronquart et al., 2012). Non-lethal sampling methods also allow for repeated measurements on the same individuals, hence the possibility to address additional trophic questions. Exploring the path of alternative non-lethally sampled tissues is therefore highly needed. However, stable isotope ratios vary among tissues within a same individual depending on several factors, including isotope routing, amino acid composition and turnover rates (Fry, 2006; Michener and Lajtha, 2007; Martinez del Rio et al., 2009). It is thus essential to test whether alternative tissues provide stable isotope measurements similar to those of reference tissues in order to ensure that they can actually be substituted. In practice, food web studies require sampling tissues with low variation in stable isotope values, so that muscle became routinely used for SIA in vertebrates (Pinnegar and Polunin, 1999). It is now virtually replaced by non-destructively sampled tissues in vertebrates, such as fish fins and scales (e.g. Jardine et al., 2011; Fincel et al., 2012; Hette-Tronquart et al., 2012), bird claws (Bearhop et al., 2003), reptile claws (Marques et al., 2011) and cetacean fins (Todd et al., 1997).

Surprisingly enough, research on the trophic ecology of amphibians is lagging behind that of other vertebrate taxa (Altig et al., 2007). Yet, amphibians likely play a pivotal role in the structure and functioning of aquatic food webs because they are both predators and preys (Schiesari et al., 2009; Solé and Rödder, 2010). Furthermore, the remarkable biphasic life history of many amphibians contributes to energy flows between terrestrial and aquatic habitats (Solé and Rödder, 2010; Trakimas et al., 2011). Amphibians also suffer severe global population declines as a result of global changes (habitat destruction, pollution, or introduction of non-native species, etc.; Beebee and Griffiths, 2005) and are one of the most threatened vertebrate taxa (Baillie et al., 2004). Therefore, any information on their trophic ecology and its variation in fluctuating environments is relevant and of potential use for their conservation. The diet of tadpoles has been more investigated since Altig et al. (2007) called for more research (see e.g. Trakimas et al., 2011; Schriever and Williams, 2013; Arribas et al., 2015; Carreira et al., 2016), but as for now relatively few SIA studies are related to the trophic ecology of amphibians. This is probably partly because non-lethal sampling methods are rarely used (but see e.g. Sepulveda et al., 2012; Gillespie, 2013; Remon et al., 2016, Lejeune et al., 2018). Only one study thoroughly explored the relevance of tail clips (i.e. the whole distal part of the tail, including bones, muscle and skin) for SIA, and showed that the carbon and nitrogen isotope ratios of the distal part of the tail were correlated to the carcass ratios in three salamander species, but with variable success (Milanovich and Maerz, 2012). As compared to tail clips, the tail fin of amphibians appears as an ideal candidate for SIA because it is a homogeneous tissue, and its regeneration is frequently recorded in wild populations following injuries by predators (Nunes et al., 2010). Validating the relevance of fin biopsies for performing SIA in amphibians is therefore highly needed.

The major objectives of this study were twofold: (1) to test whether the tail fin of amphibian species is relevant as a surrogate for muscle tissues and provide fin-derived corrective equations to estimate stable isotope ratios of carbon and nitrogen, and to address additional practical issues related to (2) the use of a topical anaesthetic, recommended for minor surgeries (Gentz, 2007; Mitchell, 2009) likely to modify stable isotope ratios, and (3) the minimum quantities of fin needed to successfully perform SIA while limiting the severity of tail fin sampling. In doing so, we want to provide a non-destructive sampling method for stable isotope research in amphibians.

\section{Materials and Methods}

\subsection{Study area and sample collection}

An extensive amphibian study took place over more than 150 ponds in the Regional Natural Park of Brière, northwestern France $\left(47^{\circ} 23^{\prime} \mathrm{N}, 02^{\circ} 12^{\prime} \mathrm{W}\right.$ ), in 2015 and 2016 (see Tréguier et al., 2018 for a detailed description of the study area). Two types of funnel traps were set over the night period: wire mesh traps (Tréguier et al., 2018) and Ortmann's traps (Drechsler et al., 2010; Fig. 1). Despite appropriate fieldwork precautions, 107 amphibians were found dead in the traps in 24 ponds, partly predated on by non-targeted trapped predators or for unknown causes, from 14 April to 22 May 2015 and from 21 April to 10 June 2016. We used all these animals in the present study. They were agile frog tadpoles (Rana dalmatina, $N=29$, one to 16 per pond from four ponds), European tree frog tadpoles (Hyla arborea, $N=14$ from one pond), adult marbled newts (Triturus marmoratus, $N=30$, one to nine per pond from nine ponds) and palmate newts (Lissotriton helveticus, $N=34$, one to six per pond from 12 ponds), altogether representing $<1 \%$ of the amphibians caught over two years. The developmental stages of tadpoles ranged from 26 to 42 (i.e. development of hind limbs; Gosner, 1960). All the collected life stages were commonly present in the ponds for a time period long enough to play a critical role in aquatic food webs. As specimens were collected from different populations in ponds displaying a variety of environmental conditions, the consistency of correlation of stable isotope ratios of carbon and nitrogen between fin and muscle across amphibian species would be a first step before transferring such relationships to other study sites. Specimens were preserved by freezing at $-20^{\circ} \mathrm{C}$ immediately after collection for further analysis.

\subsection{Sample preparation and stable isotope analyses}

In the laboratory, tail fins were rinsed with deionized water and then sampled using 2.5- and 3-mm diameter biopsy 


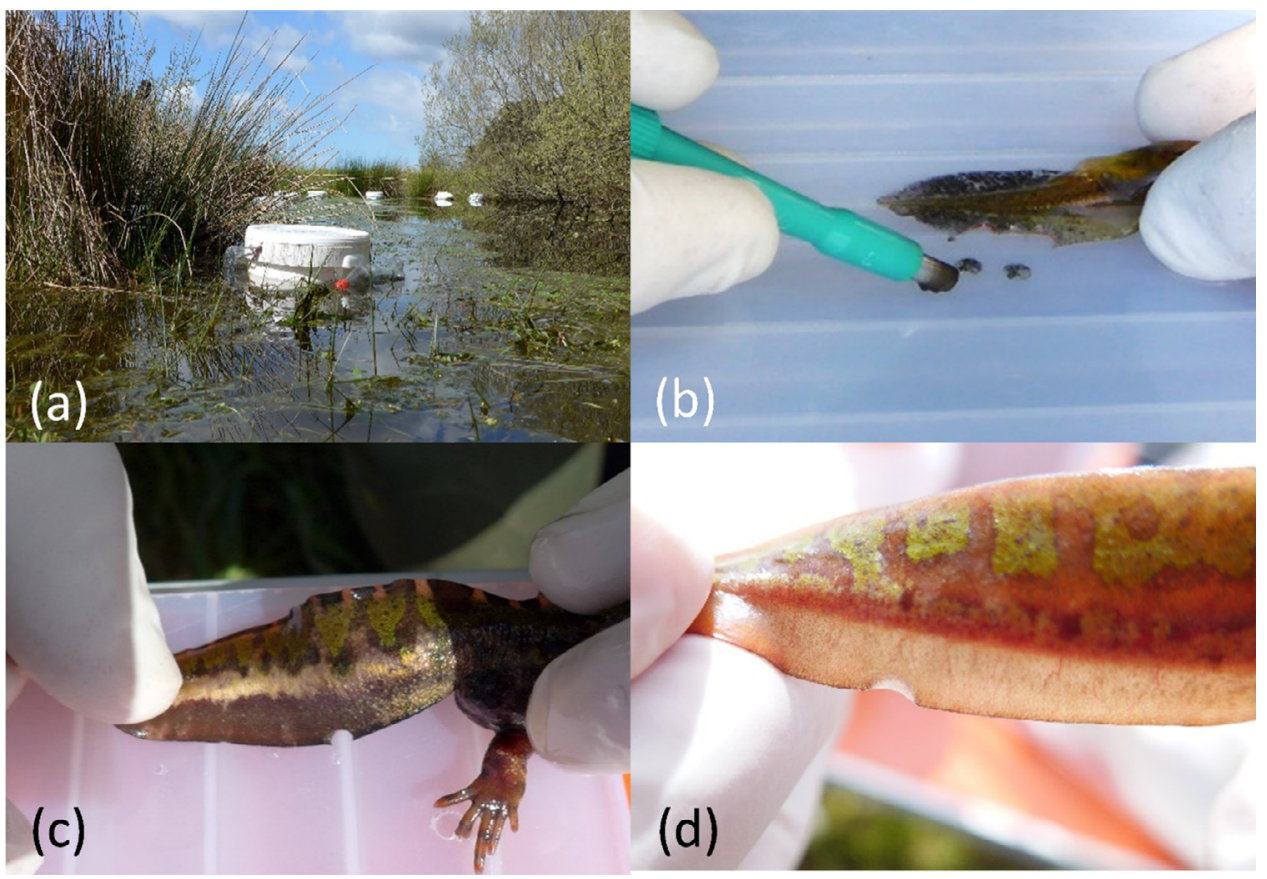

Fig. 1. Habitat and fin sampling of amphibians: (a) Ortmann's traps set in a typical pond of the study area; (b) and (c): sampling of the fin of an agile frog tadpole and a marbled newt adult, respectively; (d): regeneration of the fin of a marbled newt, 10 days after sampling.

Table 1. Mean differences in $\delta^{13} \mathrm{C}$ and $\delta^{15} \mathrm{~N}$ between fin and muscle values, and linear models (equations, $95 \%$ confidence intervals (95\% $\mathrm{CI}$ ) of the estimate and the intercept) fitting muscle $\delta^{13} \mathrm{C}$ and $\delta^{15} \mathrm{~N}$ as a function of the isotope ratios in fin tissue for each species or group of species (anuran tadpoles and urodele adults). $\delta^{13} \mathrm{C}$ values were corrected for the lipid content according to Caut et al. (2013). The significance of the mean differences and linear equations is indicated: NS: non-significant, ${ }^{*} p \leq 0.05,{ }^{* *} p<0.01,{ }^{* * *} p<0.001$.

\begin{tabular}{|c|c|c|c|c|c|c|}
\hline \multirow[t]{2}{*}{ Species } & \multirow[t]{2}{*}{$N$} & \multirow{2}{*}{ 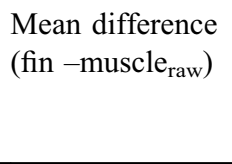 } & \multicolumn{4}{|c|}{ Linear model } \\
\hline & & & Equations & $\begin{array}{l} \pm 95 \% \mathrm{CI} \\
\text { estimate }\end{array}$ & $\begin{array}{l} \pm 95 \% \mathrm{CI} \\
\text { intercept }\end{array}$ & Adj. $r^{2}$ \\
\hline \multicolumn{7}{|l|}{$\delta^{13} \mathrm{C}$} \\
\hline Agile frog & 29 & $0.44 \pm 0.28^{* * *}$ & $\delta^{13} \mathrm{C}_{\text {muscle }}=0.85 \times \delta^{13} \mathrm{C}_{\text {fin }}-5.50 * * *$ & 0.13 & 4.39 & 0.86 \\
\hline European tree frog & 14 & $0.19 \pm 0.20^{* *}$ & $\delta^{13} \mathrm{C}_{\text {muscle }}=0.87 \times \delta^{13} \mathrm{C}_{\text {fin }}-4.80 * * *$ & 0.19 & 6.64 & 0.89 \\
\hline Marbled newt & 30 & $-0.13 \pm 0.36 \mathrm{NS}$ & $\delta^{13} \mathrm{C}_{\text {muscle }}=0.70 \times \delta^{13} \mathrm{C}_{\text {fin }}-7.43 * * *$ & 0.18 & 4.64 & 0.68 \\
\hline Palmate newt & 25 & $-1.44 \pm 0.86^{* * *}$ & $\delta^{13} \mathrm{C}_{\text {muscle }}=0.71 \times \delta^{13} \mathrm{C}_{\text {fin }}-7.03 * * *$ & 0.17 & 4.65 & 0.77 \\
\hline Anuran tadpoles & 43 & $0.36 \pm 0.28 * * *$ & $\delta^{13} \mathrm{C}_{\text {muscle }}=0.86 \times \delta^{13} \mathrm{C}_{\text {fin }}-5.01 * * *$ & 0.07 & 2.15 & 0.95 \\
\hline Urodele adults & 55 & $-0.73 \pm 0.91 * * *$ & $\delta^{13} \mathrm{C}_{\text {muscle }}=0.65 \times \delta^{13} \mathrm{C}_{\text {fin }}-8.57^{* * *}$ & 0.07 & 1.74 & 0.89 \\
\hline \multicolumn{7}{|l|}{$\delta^{15} \mathrm{~N}$} \\
\hline Agile frog & 29 & $-0.04 \pm 0.36 \mathrm{NS}$ & $\delta^{15} \mathrm{~N}_{\text {muscle }}=0.86 \times \delta^{15} \mathrm{~N}_{\text {fin }}+0.97 * * *$ & 0.07 & 0.46 & 0.96 \\
\hline European tree frog & 14 & $-0.84 \pm 0.30 * * *$ & $\delta^{15} \mathrm{~N}_{\text {muscle }}=1.04 \times \delta^{15} \mathrm{~N}_{\text {fin }}+0.67 * *$ & 0.43 & 1.77 & 0.67 \\
\hline Marbled newt & 30 & $0.37 \pm 0.45^{* * *}$ & $\delta^{15} \mathrm{~N}_{\text {muscle }}=1.01 \times \delta^{15} \mathrm{~N}_{\text {fin }}-0.48^{* * *}$ & 0.13 & 0.04 & 0.91 \\
\hline Palmate newt & 25 & $0.43 \pm 0.95^{*}$ & $\delta^{15} \mathrm{~N}_{\text {muscle }}=0.89 \times \delta^{15} \mathrm{~N}_{\mathrm{fin}}+0.40 * * *$ & 0.15 & 1.19 & 0.86 \\
\hline Anuran tadpoles & 43 & $-0.30 \pm 0.51 * * *$ & $\delta^{15} \mathrm{~N}_{\text {muscle }}=0.79 \times \delta^{15} \mathrm{~N}_{\mathrm{fin}}+1.54 * * *$ & 0.06 & 0.36 & 0.95 \\
\hline Urodele adults & 55 & $0.40 \pm 0.72 * * *$ & $\delta^{15} \mathrm{~N}_{\text {muscle }}=0.92 \times \delta^{15} \mathrm{~N}_{\text {fin }}+0.18^{* * *}$ & 0.10 & 0.73 & 0.87 \\
\hline
\end{tabular}

punches (Fig. 1 and Tab. 1 for sample sizes). In tadpoles and palmate newts, biopsy samples were taken on the welldeveloped dorsal part of the tail fin. In marbled newts, the sampling of the ventral part of the fin was preferred so as not to damage the dorsal part which is of great importance for males during courtship. One to six samples were taken per individual when possible depending on the species (agile frog: 1-4, European tree frog: 3-5, palmate newt: 3-4, marbled newt: 
3-6) to ensure that enough biological material was collected. Then, amphibians were dissected to sample their tail muscle. All samples were rinsed with deionized water before proceeding to the subsequent steps of sample preparation.

Local anaesthetics can be used for minor surgical procedures such as fin biopsy for amphibians, to limit the handling time of animals and risks as compared to water anaesthetics (Gentz, 2007; Mitchell, 2009). A prerequisite is to check beforehand whether the anaesthetic affects stable isotope values. The effect of lidocaine, a common topical anaesthetic recommended for amphibians (Wright, 2001; Gentz, 2007) was assessed by comparing the carbon and nitrogen isotope ratios of samples treated with the anaesthetic to those of control samples. Because we used most of the fin for exploring the relationships between fin and muscle, notably in palmate newts, the anaesthetic experiment was done on an approximately $1-\mathrm{cm}$ section of an intact part of the tail of individuals of the two newt species $(N=21,8$ marbled newts and 13 palmate newts). For each individual, the tail sample was divided into two parts. On one part, lidocaine gel ( $2 \%$ solution) was applied on the integument for 5 min (the recommended latent period), and then it was rinsed with deionized water to remove any lidocaine residues. The other part was only rinsed with deionized water and used as a control.

All samples were freeze-dried for $48 \mathrm{~h}$. Then they were ground to a homogeneous fine powder, except fin samples because of the small amount of tissue available. For a subset of individuals (17 agile frogs, 10 European tree frogs, 29 marbled newts and 7 palmate newts), fin samples were individually weighted after freeze-drying to calculate mean density values $\left(\mu \mathrm{g} / \mathrm{mm}^{2}\right)$ and ultimately to estimate the minimal fin surface required to successfully perform SIA. Fin samples were then gathered to constitute a unique sample per individual, except in nine marbled newts for which, due to large material supply, we analysed three different samples of fin to assess intraindividual variations in the stable isotope values (i.e. to explore whether the fin is a homogeneous tissue). Each sample was packed into a tin capsule (mean $\pm \mathrm{SD}=415.6 \pm 17.3 \mu \mathrm{g}$ ). SIA were performed by continuous-flow isotope-ratio mass spectrometry at the Stable Isotopes in Nature Laboratory (Fredericton, New Brunswick, Canada). Isotope ratios were reported as delta $(\delta)$ notations relatively to international standards (Vienna Peedee Belemnite for carbon, and atmospheric air for nitrogen). Maximum standard deviations of replicates from the International Atomic Energy Agency and working standards (i.e. the analytical errors) were $\pm 0.10 \%$ and $0.25 \%$ for $\delta^{13} \mathrm{C}$ and $\delta^{15} \mathrm{~N}$, respectively. C:N was calculated as the ratio between elemental composition $(\% \mathrm{C}: \% \mathrm{~N})$ of each sample.

\subsection{Data analysis}

Variations in lipid content among tissues are known to bias $\delta{ }^{13} \mathrm{C}$ values because lipid-rich tissues are depleted in ${ }^{13} \mathrm{C}$. The $\mathrm{C}: \mathrm{N}$ ratio is routinely used as a proxy of the lipid content of a tissue, so that when working on aquatic animal tissues with $\mathrm{C}$ : $\mathrm{N}>3.50$, it is common to correct $\delta^{13} \mathrm{C}$ values using normalization equations (e.g. Post et al., 2007; Logan et al., 2008). The mean $\mathrm{C}: \mathrm{N}$ values of fin and muscle were 3.47-3.88 and 3.37-3.53, respectively, across the four species. Two normalization equations were tested in parallel: one developed for aquatic animals (Post et al., 2007) and a second one specifically designed for amphibians (Caut et al., 2013). Both of them led to very similar results (differences $<1 \%$ in the resulting $\delta^{13} \mathrm{C}$ values), so we used the amphibian-specific equation of Caut et al. (2013) for subsequent calculations. Results from the other method are provided in Supplementary Table S1.

Statistical analyses were performed with $\mathrm{R}$ software, version 3.3.5 ( $\mathrm{R}$ core Team, 2018). The significance threshold was set to $p=0.05$. We first tested whether $\delta^{13} \mathrm{C}$ and $\delta^{15} \mathrm{~N}$ values differed between fin and muscle for each species using paired $t$-tests (or Wilcoxon signed rank tests when data did not meet assumptions of normality) and also calculated the mean difference $( \pm \mathrm{SD})$ between tissues. Linear models were used to test the link between muscle and fin isotope ratios for each species (specific models) and for grouped anuran or grouped urodele species (hereafter called generic models). The same statistical procedure was used to test the differences and then the link between treated and control samples in the anaesthetic experiment. Finally, we assessed the importance of intra-individual variation in isotope ratios in marbled newts using one-way ANOVA with the individuals as factors.

\section{Results}

After correcting $\delta^{13} \mathrm{C}$ for lipid contents (the range of the corrections was $0.11-0.40 \%$ for fin and $0.10-0.23 \%$ for muscle), fin and muscle differed in their isotope ratios by -1.44 to $0.44 \%$ for $\delta^{13} \mathrm{C}$ and by -0.84 to $0.43 \%$ or for $\delta^{15} \mathrm{~N}$, depending on the species (Tab. 1). These differences were significant in all species, except for $\delta^{13} \mathrm{C}$ in the marbled newt and for $\delta^{15} \mathrm{~N}$ in the agile frog (Tab. 1). Whether fins were enriched or depleted in stable isotopes as compared to muscle varied among the species and between the elements (Fig. 2): $\delta^{13} \mathrm{C}$ in the fin of anuran tadpoles and specifically of agile frogs was generally higher than in muscle, whereas it was the opposite in palmate newts; $\delta^{15} \mathrm{~N}$ was generally higher in the fin of newts than in muscle, as opposed to European tree frogs.

The isotope ratios of fin and muscle were strongly correlated independently of the species (Fig. 2, Tab. 1). A substantial proportion of the total variance was explained by the specific models, ranging from 0.67 to 0.96 ( $>0.80$ in five out of eight models, Tab. 1). Despite no significant difference in $\delta^{13} \mathrm{C}$ between tissues in the marbled newt, the total variance of the model was the lowest across species. The generic models also fitted well (explained variance: 0.870.95, see Tab. 1).

The application of lidocaine caused differences (mean \pm $\mathrm{SD})$ in isotope ratios between the two tissues of $-0.07 \pm 0.16$ $(p=0.06)$ for $\delta^{13} \mathrm{C}$ and $-0.09 \pm 0.11 \%$ o $(p=0.002)$ for $\delta^{15} \mathrm{~N}$. The equations linking control and treated samples (Fig. 3) were $\delta{ }^{13} \mathrm{C}_{\text {control }}=1.01 \times \delta{ }^{13} \mathrm{C}_{\text {lidocaine }}+0.37\left(r^{2}=0.98, p<0.001\right)$ and $\delta{ }^{15} \mathrm{~N}_{\text {control }}=1.02 \times \delta^{15} \mathrm{~N}_{\text {lidocaine }}-0.03\left(r^{2}=1, p<0.001\right)$.

Fin matter densities varied greatly among species, and were on average 2.75 to 7 times higher in adult newts than in tadpoles (Tab. 2). Differences in matter density were also recorded within species (see values in Tab. 2). In practice, average numbers of two $2.5-\mathrm{mm}$ diameter fin biopsies were 


\section{(a) Anuran tadpoles}
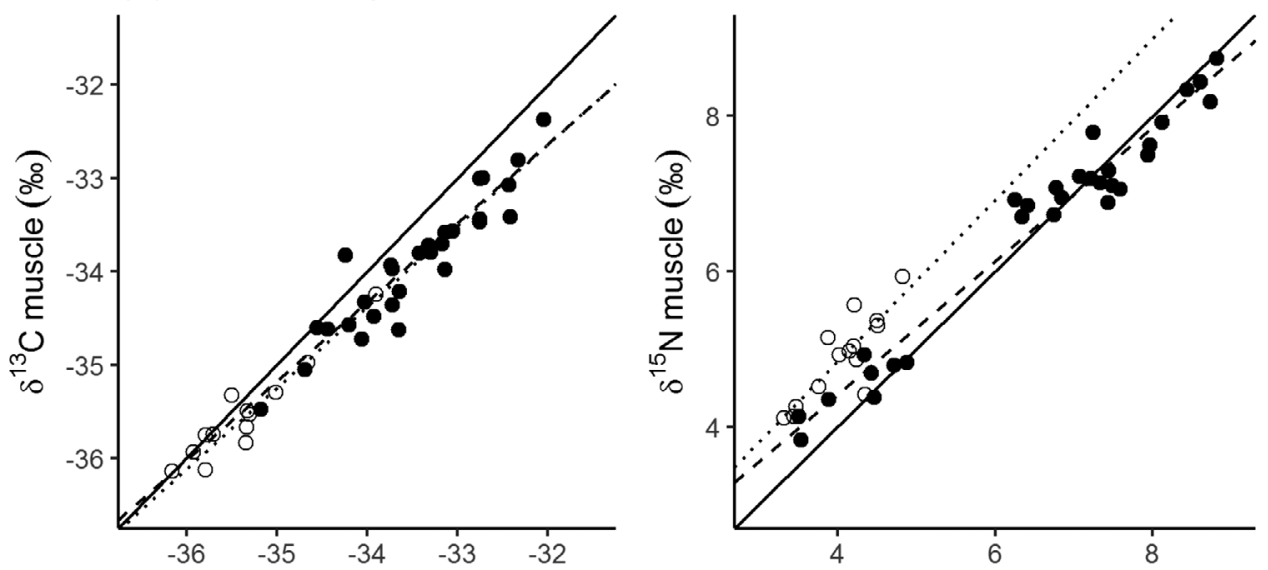

(b) Urodele adults
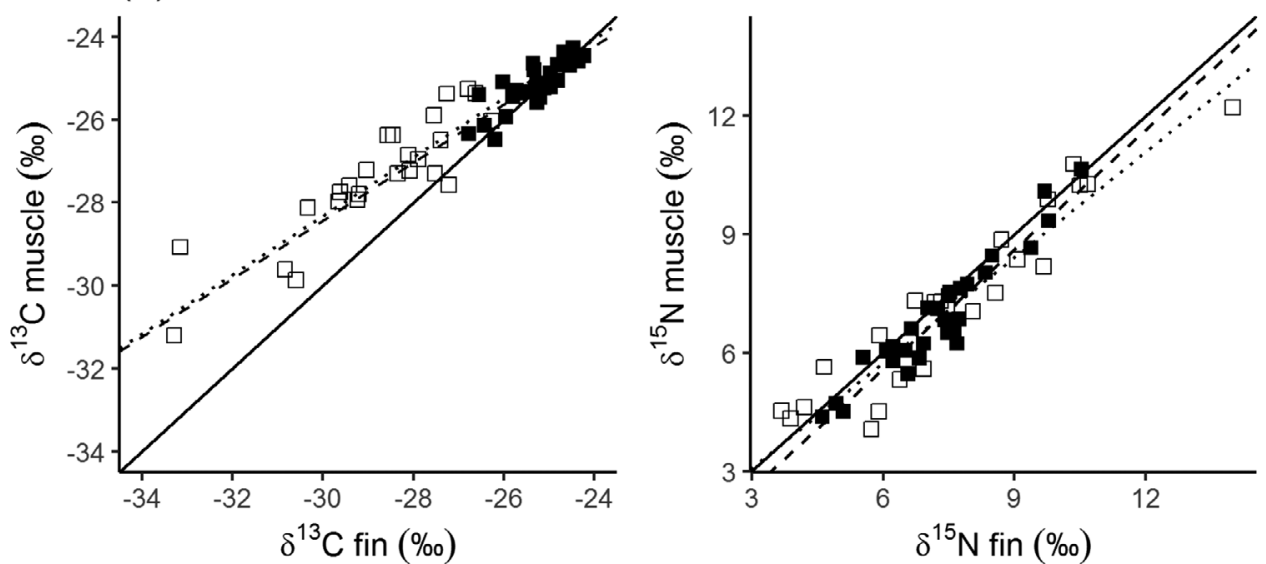

Fig. 2. Linear regressions of $\delta^{13} \mathrm{C}$ (left) and $\delta^{15} \mathrm{~N}$ (right) between muscle and fin in (a) anuran tadpoles and (b) newt adults. Empty circles on a dotted line represent the European tree frog, full circles on a dashed line the agile frog, empty squares on a dotted line and full squares on a dashed line the palmate newt and marbled newts, respectively. Plain lines represent $y=x$.
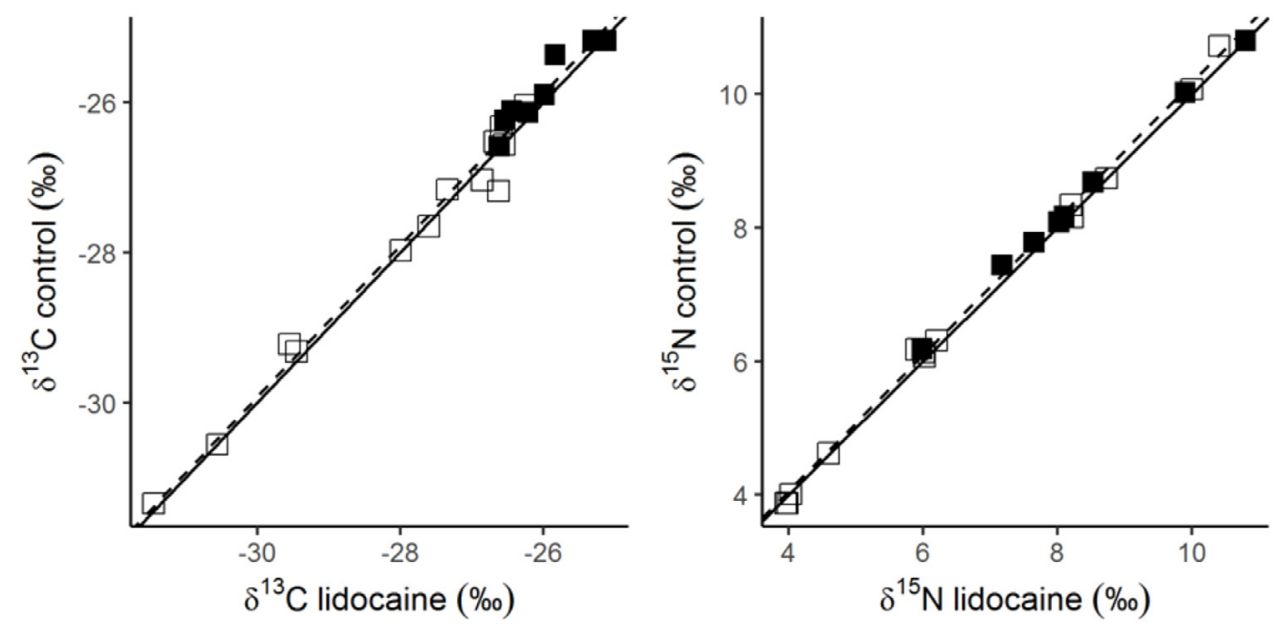

Fig. 3. Relationships between control and lidocaine-treated samples for $\delta^{13} \mathrm{C}$ and $\delta^{15} \mathrm{~N}$. Filled squares, marbled newt samples; empty squares, palmate newt samples. Dashed lines represent the linear model and plain lines indicate $y=x$. 
Table 2. Density of amphibian tail fin, and conversion into the fin surface required to produce $100 \mu \mathrm{g}$ of freeze-dried matter (i.e. the minimum mass required for nitrogen-rich biological material for stable isotope measurements).

\begin{tabular}{|c|c|c|c|c|c|}
\hline \multirow[t]{2}{*}{ Species } & \multirow{2}{*}{$\begin{array}{l}\text { Number of individuals } \\
\text { (fin samples) }\end{array}$} & \multicolumn{2}{|c|}{ Freeze-dried matter density $\left(\mu \mathrm{g} \mathrm{mm}^{-2}\right)$} & \multicolumn{2}{|c|}{ Fin surface required $\left(\mathrm{mm}^{-2}\right)$} \\
\hline & & Mean \pm SD & Range & Mean \pm SD & Range \\
\hline Agile frog & $17(62)$ & $13.7 \pm 4.7$ & $6.9-22.7$ & $9.0 \pm 2.8$ & $5.5-16.7$ \\
\hline European tree frog & $10(39)$ & $7.9 \pm 2.4$ & $5.1-12.4$ & $14.4 \pm 4.1$ & $9.0-20.8$ \\
\hline Marbled newt & 29 (139) & $55.3 \pm 9.1$ & $23.1-89.4$ & $2.0 \pm 0.4$ & $1.0-4.4$ \\
\hline Palmate newt & $7(23)$ & $37.7 \pm 4.2$ & $25.4-62.2$ & $3.0 \pm 0.2$ & $1.8-4.0$ \\
\hline
\end{tabular}

required to produce $100 \mu \mathrm{g}$ of freeze-dried matter (see Sect. 4 regarding the minimum required mass to achieve accurate stable isotope measurements) for agile frog tadpoles, two 3-mm diameter fin biopsies for European tree frog tadpoles and only one 2-mm diameter fin biopsy for adult marbled and palmate newts. Finally, the intra-individual variations in isotope values recorded in marbled newts were very low $(1.6 \%$ for $\delta^{13} \mathrm{C}$ and $1.7 \%$ for $\delta^{15} \mathrm{~N}, 3$ fin replicates $\times 9$ newts; oneway ANOVA, $p<0.001)$.

\section{Discussion}

The tail fin of amphibians was found to be a highly relevant substitute for muscle tissue for conducting SIA. The strong relationships between the tail fin and muscle isotope ratios suggest that the two tissues had similar turnover rates and integrated comparable diet information. Mean differences in $\delta^{15} \mathrm{~N}$ between the two tissues were low compared to common trophic discrimination factors (TDF) found in several amphibian species: $3.80 \pm 0.46 \%$ in Caut et al. (2013), $3.66 \pm 0.48 \%$ and $2.23 \pm 0.49 \%$ in San Sebastián et al. (2015). Moreover, these differences were marginal compared to other sources of error, such as the variability in the TDF that can be used to characterize trophic networks (see the values above, and also Martinez del Rio et al., 2009), even if the error was higher in the European tree frog than in other species. The same reasoning can apply to $\delta^{13} \mathrm{C}$ : the mean differences $\delta^{13} \mathrm{C}$ between the two tissues were lower than the TDF values reported for amphibians in the literature and comparable to the variability among them $(1.19 \pm 0.31$ in Caut et al. (2013), $1.56 \pm 0.64$ and $0.91 \pm 0.49$ in San Sebastián et al. (2015)), except in the palmate newt. As a result, this potential error due to fin-muscle differences were probably too low to cause important misinterpretations in food web studies (see also Jardine et al., 2011); but this was not true for all species, especially for $\delta^{13} \mathrm{C}$ in the palmate newt and to a lesser extent for $\delta^{15} \mathrm{~N}$ in the European tree frog. These specific results remain unexplained.

Both the specific and the generic equations were adequate to estimate muscle values from fin samples. By comparison, existing corrective equations built for tail clips in three salamander species were less powerful (Milanovich and Maerz, 2012). One potential explanation could be that the tissue composition was more heterogeneous in their case. The equations we used for the two anuran species were very similar, and so were the equations for the two newt species. This is not surprising given that both anuran tadpoles are essentially phytophagous, and both newt species are predators.
The fact that the amphibians came from different ponds with various environmental conditions (except the European tree frog) did not seem to affect the results. Therefore, it can be hypothesized that the relationship between fin and muscle was robust for other study areas, although further exploration of this question would be welcome. We recommend building specific equations for any new target species; nevertheless, the generic equations we implemented represent a valuable alternative depending on the diet of the species.

The present study also answers important practical questions. Topical anaesthetics are used for potentially painful surgical procedures on amphibians, but their application could influence the isotope ratios of the tissues. The deviations in $\delta^{13} \mathrm{C}$ and $\delta^{15} \mathrm{~N}$ due to the application of lidocaine ( $2 \%$ solution) were negligible as they did not exceed the commonly recorded analytical errors. Nonetheless, the adverse effects of anaesthetics on the skin of amphibians are poorly known, and when a biopsy sample is very small, it is recommended to proceed without applying any chemical anaesthetics (Wright, 2001; Canadian Council on Animal Care, 2004). This is the case for fin biopsies dedicated to SIA, because the minimal quantity of tail fin required to accurately measure $\delta^{13} \mathrm{C}$ and $\delta^{15} \mathrm{~N}$ can be as low as $100 \mu \mathrm{g}$ for nitrogen-rich samples (depending on the analytic optimization of SIA platforms), corresponding to fin surfaces as small as $10-15 \mathrm{~mm}^{2}$ for tadpoles and $2 \mathrm{~mm}^{2}$ for newts. We recommend sampling these minimal fin areas, or slightly greater areas in accordance with the instructions of SIA laboratories, because these areas are far below the $30 \%$ tail clipping that did not affect larval survival in salamanders (Segev et al., 2015). Moreover, the tail of amphibians is a lure for predators and is routinely injured in the wild (Nunes et al., 2010). The low intra-individual variations in $\delta^{13} \mathrm{C}$ or $\delta^{15} \mathrm{~N}$ in the marbled newt indicate that the fin is a relatively homogenous tissue, and we therefore suggest that sampling can be done on the part of the fin that is considered to be the least detrimental for the animals. Finally, in additional field work, we observed the complete regeneration of the tail fin in marbled newts, and sampled individuals were unrecognizable within 3 weeks after sampling (unpublished data, Fig. 1).

Using SIA to address trophic issues used to be highly constrained in amphibians because it often implied destructive sampling techniques. The equations implemented in this study allow us to accurately estimate $\delta^{13} \mathrm{C}$ or $\delta^{15} \mathrm{~N}$ in muscle, a reference tissue in SIA, from the non-lethal fin sampling of larvae and adults in several amphibian species. We hope that our findings will encourage new investigations on the trophic ecology of amphibians. Furthermore, exploring SIA using fin biopsy opens onto promising prospects, such as tracking 
trophic status changes at the individual level over time. More generally, a better understanding of the trophic ecology of amphibian populations is critical for predicting the consequences of global changes, and is undoubtedly of great interest for their conservation.

\section{Supplementary material}

Supplementary Table S1. Mean difference in $\delta^{13} \mathrm{C}$ and $\delta^{15} \mathrm{~N}$ between fin and muscle values, and linear models (equations, $95 \%$ confidence intervals $(95 \% \mathrm{CI})$ of the estimate and the intercept) fitting muscle $\delta^{13} \mathrm{C}$ and $\delta^{15} \mathrm{~N}$ as a function of the isotope ratios in fin tissue for each species or group of species (anuran tadpoles and urodele adults). $\delta^{13} \mathrm{C}$ values were corrected for lipid content according to Post et al. (2007). The significance of the mean differences and linear equations is indicated. NS: non-significant, ${ }^{*} p<0.05, * * p<0.01$, $* * * p<0.001$.

The Supplementary Material is available at https:/www. kmae-journal.org/10.1051/kmae/2018040/olm.

Acknowledgements. This study was funded by the Agence Française pour la Biodiversité (research program supervised by J.M.P.) and the Ministère de l'Education Nationale, de l'Enseignement Supérieur et de la Recherche (Ph.D. grant to N.B.). This work was carried out under the licenses 08/2015 and 07/2016 delivered by the Préfecture de la Loire-Atlantique. We thank the Parc Natural Régional de Brière, notably J.P. Damien, for supporting our research activities on amphibian ecology. The authors declare that they have no conflict of interest. We are also grateful to two anonymous reviewers for their constructive comments on an earlier version of the manuscript. A. Buchwalter edited the final version of the article.

\section{References}

Altig R, Whiles MR, Taylor CL. 2007. What do tadpoles really eat? Assessing the trophic status of an understudied and imperiled group of consumers in freshwater habitats. Freshw Biol 52: 386-395.

Arribas R, Díaz-Paniagua C, Caut S, Gomez-Mestre I. 2015. Stable isotopes reveal trophic partitioning and trophic plasticity of a larval amphibian guild. PLoS One 10: e0130897.

Baillie J, Hilton-Taylor C, Stuart SN. 2004. 2004 IUCN red list of threatened species: a global species assessment. IUCN - Gland, Switzerland: The World Conservation Union.

Bearhop S, Furness RW, Hilton GM, Votier SC, Waldron S. 2003. A forensic approach to understanding diet and habitat use from stable isotope analysis of (avian) claw material. Funct Ecol 17: 270-275.

Beebee TJC, Griffiths RA. 2005. The amphibian decline crisis: a watershed for conservation biology? Biol Conserv 125: 271-285.

Canadian Council on Animal Care. 2004. Recommandations du CCPA spécifiques aux espèces: les amphibiens et les reptiles. Retrieved from https://www.ccac.ca/Documents/Normes/Ligne s_directrices/Animaux_sauvages_Amphibiens_Reptiles.pdf (accessed 25 May 2018).

Carreira BM, Segurado P, Orizaola G, Gonçalves N, Pinto V, Laurila A, Rebelo R. 2016. Warm vegetarians? Heat waves and diet shifts in tadpoles. Ecology 97: 2964-2974.

Caut S, Angulo E, Díaz-Paniagua C, Gomez-Mestre I. 2013. Plastic changes in tadpole trophic ecology revealed by stable isotope analysis. Oecologia 173: 95-105.
Drechsler A, Bock D, Ortmann D, Steinfartz S. 2010. Ortmanns funnel trap - a highly efficient tool for monitoring amphibian species. Herpetol Notes 3: 13-21.

Fincel MJ, Vandehey JA, Chipps SR. 2012. Non-lethal sampling of walleye for stable isotope analysis: a comparison of three tissues. Fish Manag Ecol 19: 283-292.

Fry B. 2006. Stable Isotope Ecology. New York, NY: Springer, 308 pp.

Gentz EJ. 2007. Medicine and surgery of amphibians. ILAR $J$ 48: 255-259.

Gillespie JH. 2013. Application of stable isotope analysis to study temporal changes in foraging ecology in a highly endangered amphibian. PLoS One 8: e53041.

Gosner KL. 1960. A simplified table for staging anuran embryos and larvae with notes on identification. Herpetologica 16: 183-190.

Hette-Tronquart N, Mazeas L, Reuilly-Manenti L, Zahm A, Belliard J. 2012. Fish fins as non-lethal surrogates for muscle tissues in freshwater food web studies using stable isotopes. Rapid Commun Mass Spectrom 26: 1603-1608.

Jardine TD, Hunt RJ, Pusey BJ, Bunn SE. 2011. A non-lethal sampling method for stable carbon and nitrogen isotope studies of tropical fishes. Mar Freshw Res 62: 83.

Layman CA, Araujo MS, Boucek R, Hammerschlag-Peyer CM, Harrison E, Jud ZR, Matich P, Rosenblatt AE, Vaudo JJ, Yeager LA, et al. 2012. Applying stable isotopes to examine food-web structure: an overview of analytical tools. Biol Rev 87: $545-562$.

Lejeune B, Sturaro N, Lepoint G, Denoël M. 2018. Facultative paedomorphosis as a mechanism promoting intraspecific niche differentiation. Oikos 127: 427-439.

Logan JM, Jardine TD, Miller TJ, Bunn SE, Cunjak RA, Lutcavage ME. 2008. Lipid corrections in carbon and nitrogen stable isotope analyses: comparison of chemical extraction and modelling methods. J Anim Ecol 77: 838-846.

Marques TS, Tassoni-Filho M, Ferronato BO, Guardia I, Verdade LM, de Camargo PB. 2011. Isotopic signatures $(\delta 13 \mathrm{C}$ and $\delta 15 \mathrm{~N})$ of muscle, carapace and claw in Phrynops geoffroanus (Testudines: Chelidae). Zoologia 28: 407-410.

Martinez del Rio C, Wolf N, Carleton SA, Gannes LZ. 2009. Isotopic ecology ten years after a call for more laboratory experiments. Biol Rev 84: 91-111.

Michener RH, Lajtha K. 2007. Stable Isotopes in Ecology and Environmental Science. Malden, MA: Blackwell Pub, $566 \mathrm{pp}$.

Milanovich J, Maerz JC. 2012. Assessing the use of non-lethal tail clips for measuring stable isotopes of plethodontid salamanders. Herpetol Conserv Biol 7: 67-74.

Mitchell MA. 2009. Anesthetic considerations for amphibians. J Exot Pet Med 18: 40-49.

Nielsen JM, Clare EL, Hayden B, Brett MT, Kratina P. 2018. Diet tracing in ecology: method comparison and selection. Methods Ecol Evol 9: 278-291.

Nunes AL, Cruz MJ, Tejedo M, Laurila A, Rebelo R. 2010. Nonlethal injury caused by an invasive alien predator and its consequences for an anuran tadpole. Basic Appl Ecol 11: 645-654.

Pinnegar JK, Polunin NVC. 1999. Differential fractionation of $\delta{ }^{13} \mathrm{C}$ and $\delta^{15} \mathrm{~N}$ among fish tissues: implications for the study of trophic interactions. Funct Ecol 13: 225-231.

Post DM, Layman CA, Arrington DA, Takimoto G, Quattrochi J, Montaña CG. 2007. Getting to the fat of the matter: models, methods and assumptions for dealing with lipids in stable isotope analyses. Oecologia 152: 179-189. 
R Core Team. 2018. R: A Language and Environment for Statistical Computing. Vienna, Austria: R Foundation for Statistical Computing.

Remon J, Bower DS, Gaston TF, Clulow J, Mahony MJ. 2016. Stable isotope analyses reveal predation on amphibians by a globally invasive fish (Gambusia holbrooki). Aquat Conserv Mar Freshw Ecosyst 26: 724-735.

San Sebastián O, Navarro J, Llorente GA, Richter-Boix Á. 2015. Trophic strategies of a non-native and a native amphibian species in shared ponds. PLoS One 10: e0130549.

Schiesari L, Werner EE, Kling GW. 2009. Carnivory and resourcebased niche differentiation in anuran larvae: implications for food web and experimental ecology. Freshw Biol 54: 572-586.

Schriever TA, Williams DD. 2013. Ontogenetic and individual diet variation in amphibian larvae across an environmental gradient. Freshw Biol 58: 223-236.

Segev O, Polevikove A, Blank L, Goedbloed D, Küpfer E, Gershberg A, Koplovich A, Blaustein L. 2015. Effects of tail clipping on larval performance and tail regeneration rates in the near eastern fire salamander, Salamandra infraimmaculata. PLoS One 1: 12.
Sepulveda AJ, Lowe WH, Marra PP. 2012. Using stable isotopes to test for trophic niche partitioning: a case study with stream salamanders and fish. Freshw Biol 57: 1399-1409.

Solé M, Rödder D. 2010. Dietary assessments of adult amphibians. In: Dodd $\mathrm{CK}$, ed. Amphibian Ecology and Conservation: A Handbook of Techniques. Oxford: Oxford University Press, pp. 167-184.

Todd S, Ostrom P, Lien J, Abrajano J. 1997. Use of biopsy samples of humpback whale (Megaptera novaeangliae) skin for stable isotope $\left(\delta^{13} \mathrm{c}\right)$ determination. J Northwest Atl Fish Sci 22: 71-76.

Trakimas G, Jardine TD, Barisevičiute R, Garbaras A, Skipitytė R, Remeikis V. 2011. Ontogenetic dietary shifts in European common frog (Rana temporaria) revealed by stable isotopes. Hydrobiologia 675: 87-95.

Tréguier A, Roussel J-M, Bélouard N, Paillisson J-M. 2018. Is it a hindrance for an invasive aquatic species to spread across scattered habitat patches? Aquat Conserv Mar Freshw Ecosyst 28: 610-618.

Wright KM. 2001. Surgical techniques. In: Wright KM, Whitaker BR, eds. Amphibian Medicine and Captive Husbandry. Malabar FL: Krieger Publishing Company, pp. 273-283.

Cite this article as: Bélouard N, Petit EJ, Huteau D, Oger A, Paillisson J-M. 2019. Fins are relevant non-lethal surrogates for muscle to measure stable isotopes in amphibians. Knowl. Manag. Aquat. Ecosyst., 420, 2. 